research and treatment centres and, in some countries, ministries of health.

Activities. The UICC creates and carries out programmes around the world in collaboration with several hundred volunteer experts, most of whom are professionally active in UICC member organizations. It promotes co-operation between cancer organizations, researchers, scientists, health professionals and cancer experts, with a focus in four key areas: building and enhancing cancer control capacity, tobacco control, populationbased cancer prevention and control, and transfer of cancer knowledge and dissemination. The next UICC World Cancer Congress is scheduled to take place in Beijing in 2010.

Address: 3 rue du Conseil-Général, 1205-Geneva, Switzerland. Website: http://www.uicc.org

President: Franco Cavalli (Switzerland).

Executive Director: Isabel Mortara (Switzerland).

\section{Inter-Parliamentary Union (IPU)}

Founded in 1889 by William Randal Cremer (UK) and Frédéric Passy (France), the Inter-Parliamentary Union was the first permanent forum for political multilateral negotiations. The Union is a centre for dialogue and parliamentary diplomacy among legislators representing every political system and all the main political leanings in the world. It was instrumental in setting up what is now the Permanent Court of Arbitration in The Hague.

Activities. The IPU fosters contacts, co-ordination and the exchange of experience among parliaments and parliamentarians of all countries; considers questions of international interest and concern, and expresses its views on such issues in order to bring about action by parliaments and parliamentarians; contributes to the defence and promotion of human rights-an essential factor of parliamentary democracy and development; contributes to better knowledge of the working and development of representative institutions and to the strengthening of representative democracy.

Membership. The IPU had 146 members and seven associate members in Feb. 2008.

Headquarters: Chemin du Pommier 5, C.P. 330, 1218

Le Grand Saconnex, Geneva 19, Switzerland.

Website: http://www.ipu.org

President: Pier Ferdinando Casini (Italy).

Secretary-General: Anders B. Johnsson (Sweden).

\section{Interpol (International Criminal Police Organization)}

Organization. Interpol was founded in 1923, disbanded in 1938 and reconstituted in 1946. The International Criminal Police Organization-Interpol was founded to ensure and promote the widest possible mutual assistance between all criminal police authorities within the limits of the law existing in the different countries worldwide and the spirit of the Universal Declaration of Human Rights, and to establish and develop all institutions likely to contribute effectively to the prevention and suppression of ordinary law crimes.

Aims. Interpol provides a co-ordination centre (General Secretariat) for its 186 member countries. Its priority areas of activity concern criminal organizations, public safety and terrorism, drug-related crimes, financial crime and high-tech crime, trafficking in human beings and tracking fugitives from justice. Interpol centralizes records and information on international offenders; it operates a worldwide communication network.

Interpol's General Assembly is held annually. The General Assembly is the body of supreme authority in the organization. It is composed of delegates appointed by the members of the organization.

Interpol's Executive Committee, which meets four times a year, supervises the execution of the decisions of the General Assembly. The Executive Committee is composed of the president of the organization, the three vice-presidents and nine delegates.

Interpol's General Secretariat is the centre for co-ordinating the fight against international crime. Its activities, undertaken in response to requests from the police services and judicial authorities in its member countries, focus on crime prevention and law enforcement.

As of Feb. 2008 Interpol's Sub-Regional Bureaus were located in Abidjan, Buenos Aires, San Salvador, Harare and Nairobi. Interpol's Liaison Office for Asia is located in Bangkok.

Headquarters: 200 Quai Charles de Gaulle, 69006 Lyon,

France.

Website: http://www.interpol.int

President (acting): Arturo Herrera Verdugo (Chile).

\section{Islamic Development Bank}

The Agreement establishing the IDB (Banque islamique de développement) was adopted at the Second Islamic Finance Ministers' Conference held in Jeddah, Saudi Arabia in Aug. 1974. The Bank, which is open to all member countries of the Organization of the Islamic Conference, commenced operations in 1975. Its main objective is to foster economic development and social progress of member countries and Muslim communities individually as well as jointly in accordance with the principles of the Sharia. It is active in the promotion of trade and the flow of investments among member countries, and maintains a Special Assistance Fund for member countries suffering natural calamities. The Fund is also used to finance health and educational projects aimed at improving the socio-economic conditions of Muslim communities in non-member countries. A US $\$ 1.5 \mathrm{bn}$. IDB Infrastructure Fund was launched in 1998 to invest in projects such as power, telecommunications, transportation, energy, natural resources, petro-chemical and other infrastructurerelated sectors in member countries.

Members (56 as of Feb. 2008). Afghanistan, Albania, Algeria, Azerbaijan, Bahrain, Bangladesh, Benin, Brunei, Burkina Faso, Cameroon, Chad, Comoros, Côte d'Ivoire, Djibouti, Egypt, Gabon, The Gambia, Guinea, Guinea-Bissau, Indonesia, Iran, Iraq, Jordan, Kazakhstan, Kuwait, Kyrgyzstan, Lebanon, Libya, Malaysia, Maldives, Mali, Mauritania, Morocco, Mozambique, Niger, Nigeria, Oman, Pakistan, Palestine, Qatar, Saudi Arabia, Senegal, Sierra Leone, Somalia, Sudan, Suriname, Syria, Tajikistan, Togo, Tunisia, Turkey, Turkmenistan, Uganda, United Arab Emirates, Uzbekistan, Yemen.

Official language: Arabic. Working languages: English, French. Headquarters: PO Box 5925, Jeddah 21432, Saudi Arabia.

President: Ahmed Mohamed Ali (Saudi Arabia). 